\title{
A Study of Classroom Teaching Based on Corpora in English Majors
}

\author{
Tan Zhenghua \\ School of foreign languages, Jianghan University \\ Wuhan, Hubei Province, China \\ 1548297043@qq.com
}

\begin{abstract}
This paper analyzes the teaching objectives and classroom activities of the demonstration classes, based on English or Chinese corpuses, given by 30 contestants from English major,2 014, Jianghan University. It is found that some contestants get active and productive in the procedures of the teaching class. Classroom activities about discussions demonstrate an inspiration to students' learning potential. In accordance with the college English curriculum standards, the specific features of teaching materials and the language competence of students, the paper further focuses on the significance of college English major teaching goals. Meanwhile, the significance of classroom teaching based on English \&Chinese corpuses has been stressed.
\end{abstract}

Keywords-classroom teaching; teaching objectives; teaching activities; teaching design; English\& Chinese corpuses

\section{INTRODUCTION}

With the development of computer technology, the study of corpus linguistic based on linguistic and computer science has been developed correspondingly. Corpus based translation studies was put forward by Baker (1993), Since 1995, Mona Baker and his team began to build the world's first translation corpus. Researchers have been fulfilling the study of translator's style (Baker 2000), the study of translation norms (Kenny 2001), the study of translation universals (Baker 1996; Laviosa 1998a 1998b; Kenny, 1998, 2001; Olohan Baker 2000).It is significant that Corpus linguistic aims at the genuine linguistic data and a great deal of language materials has been analysed macroscopically ( Yang,2002 ). Many corpuses have been build in different types and sizes in the world since the Brown Corpus built in US, such as Collins Birmingham University International Language Database, The British National Corpus, International Corpus of English and Corpus of Contemporary American English etc. Researchers study the nature of languages and the changes of languages in language teaching and research with the help of corpuses.

There are two ways in the teaching practice of corpuses. One is the introduction, appliance, exploration, and learning and teaching of corpuses the other is to compile dictionaries, grammar text books, and develop multimedia software, language software, etc.

\section{LITERATURE}

The Corpus is often referred to the collection of language materials, the use of electronic forms of language materials, and the natural language of written or spoken language collection. It is based on the electronic computer as the carrier of language knowledge (Sun,2011). As a new type of network information resources, the development of corpus has greatly enriched the language learning and teaching resources, and reflects the advanced educational technology and learning ideas.

The appliance of corpuses in English teaching has been classified into three levels:(1)corpuses and teaching sources;(2)corpuses and class teaching;(3)corpuses and teaching(He,2004).In the past 5 years(2010-2014), 172 researches have been published in the essential foreign language periodicals, such as ,foreign language teaching and research, Foreign Language World, Journal of Foreign Languages, Modern Foreign Languages, Chinese Translators Journal foreign language research, Foreign Languages in China, Computer-assisted Foreign Language Education, foreign language education, foreign language learning theory and practice. 
Table I

\begin{tabular}{|c|c|c|c|c|c|}
\hline amount $y$ year & 2010 & 2011 & 2012 & 2013 & 2014 \\
\hline $\begin{array}{c}\text { foreign } \\
\text { language } \\
\text { teaching and } \\
\text { research, }\end{array}$ & 4 & 3 & 6 & 6 & 5 \\
\hline $\begin{array}{c}\text { Journal of } \\
\text { Foreign } \\
\text { Languages, }\end{array}$ & 2 & 3 & 7 & 4 & 7 \\
\hline $\begin{array}{c}\text { Modern } \\
\text { Foreign } \\
\text { Languages, }\end{array}$ & 2 & 1 & 3 & 5 & 2 \\
\hline $\begin{array}{c}\text { Foreign } \\
\text { Language } \\
\text { World, }\end{array}$ & 2 & 0 & 1 & 4 & 2 \\
\hline $\begin{array}{c}\text { Chinese } \\
\text { Translators } \\
\text { Journal }\end{array}$ & 1 & 0 & 1 & 6 & 3 \\
\hline $\begin{array}{c}\text { foreign } \\
\text { language } \\
\text { research, }\end{array}$ & 0 & 0 & 7 & 4 & 5 \\
\hline $\begin{array}{c}\text { Foreign } \\
\text { Languages in } \\
\text { China, }\end{array}$ & 1 & 1 & 1 & 5 & 3 \\
\hline $\begin{array}{l}\text { Computer- } \\
\text { assisted } \\
\text { Foreign } \\
\text { Language } \\
\text { Education, }\end{array}$ & 11 & 6 & 8 & 6 & 10 \\
\hline $\begin{array}{c}\text { foreign } \\
\text { language } \\
\text { education, }\end{array}$ & 2 & 1 & 2 & 1 & 8 \\
\hline $\begin{array}{c}\text { foreign } \\
\text { language } \\
\text { learning } \\
\text { theory and } \\
\text { practice. }\end{array}$ & 0 & 0 & 0 & 6 & 4 \\
\hline total & 25 & 15 & 36 & 47 & 49 \\
\hline proportion & $14.5 \%$ & $8.7 \%$ & $20.9 \%$ & $27.3 \%$ & $28.5 \%$ \\
\hline
\end{tabular}

According to Table 1,the amount of researches on English teaching based on corpuses has been increasing as well as foreign language teaching research papers combined with corpuses recently the appliance of corpuses makes the content of statistical analysis of language more real, the quantity is more extensive, the retrieval is more quick and so on. This shows that more and more people pay attention to the research in this field. The main reason is that the corpus has its own advantages. With the further study of the research on corpus, how to use the network corpus to construct the English teaching resources more effectively will get more significant.

\section{ENGLISH CLASSROOM TEACHING OBJECTIVES AND EVALUATION}

"The national medium and long term educational reform and development plan (2010 -2020 years)" stresses that the mission of universities is to "train a large number of international professionals with an international perspective and be proficient in international affairs and international competition." Therefore, on the one hand, foreign language learning needs to be trained in listening, speaking, reading and writing and other language skills, on the other hand, students need to acquire the general knowledge and professional knowledge, so as to further improve the effectiveness of foreign language learning.

Meanwhile, Language courses carry the task of cultivating students' critical thinking and autonomous learning ability. Therefore, College English class should set goals of "language", "subject knowledge" and "ability training", and flexibly coordinate the relationship between different goals. According to the teaching syllabus, in the process of English classroom teaching, the "long-term goal" and "short-term goal" and "macro goal" and "micro goal" should be designed. Long term goals or macro objectives are generally the goal of the whole teaching period in one academic year or one semester, and the short-term goals or micro goals are the teaching goals of a class or a week. The design of the long-term or the macro goals is to meet the need of the improvement of students' English language ability and English curriculum standard .The short-term goal or the micro goal is the way to fulfill the long-term goal or the macros goal.

Evaluation of a foreign language class is based on whether a student's foreign language proficiency has been improved or not (Gass 1997; Ellis 2005, 2012). The improvement of language proficiency is a gradual process. a class of teaching effects is often not immediately reflected by the students' statements. Currently the evaluation of a class is mainly through the observation of teaching design and activities. Observation is the main basis principles of education and psychology (such as teaching students in accordance with their aptitude, step by step, etc.) and observation of language learning characteristics ( knowledge and skills , linguistic competence and communicative competence ).Another important aspect of classroom teaching evaluation is whether there is a clear teaching goal, the goal meets the needs of students, and teaching activities achieve the goal or not. At the same time, the assessment is based on students to participate in language practice activities in a classroom ,learn or practice language skills, and have opportunities to display language skills (Shu 2006,2012,2013; Wang,2012).

\section{TEACHING ACTIVITY DESIGN}

This study aims at English majors, 2014 grade. All the 30 students are divided into 5 groups which are named group 1,2,3,4,5.Teaching materials: How to translate the word "exploration". The detailed contents are as the following Table 2 . 
Table II

\begin{tabular}{|c|c|}
\hline $\begin{array}{l}\text { Teaching } \\
\text { objectives }\end{array}$ & $\begin{array}{l}\text { Improvement of students' translation } \\
\text { proficiency }\end{array}$ \\
\hline $\begin{array}{l}\text { Content } \\
\text { courses }\end{array}$ & $\begin{array}{l}\text { How to translate the word } \\
\text { "exploration" }\end{array}$ \\
\hline $\begin{array}{l}\text { Sources } \\
\text { students }\end{array}$ & Students of English major,2014 \\
\hline classroom & Multimedia classroom \\
\hline Students & 30 \\
\hline $\begin{array}{l}\text { Translation } \\
\text { criterion(Three } \\
\text { Principles of } \\
\text { Translation by } \\
\text { Alexander } \\
\text { Fraser Tytler) }\end{array}$ & $\begin{array}{l}\text { 1.A translation should give a } \\
\text { complete transcript of the ideas of the } \\
\text { original work. } \\
\text { 2. The style and manner of writing } \\
\text { should be of the same character as } \\
\text { that of the original. } \\
\text { 3.A translation should have all the } \\
\text { ease of the original composition. }\end{array}$ \\
\hline $\begin{array}{l}\text { Teaching } \\
\text { procedures }\end{array}$ & $\begin{array}{l}\text { 1, Present teaching materials in the } \\
\text { form of PPT( } 3 \text { minutes) } \\
\text { 2, Analyze materials difficulties in } \\
\text { groups(7 minutes) } \\
\text { 3, Group discussion and translation } \\
\text { presentation.(20minutes) } \\
\text { 4, Comparison and contrast of } \\
\text { translations offered by each } \\
\text { group(10 minutes) } \\
\text { 5, Reference translations are } \\
\text { presented by teachers. } \\
\text { 6, Commenting on } \\
\text { translations by teachers }\end{array}$ \\
\hline $\begin{array}{l}\text { Discussion } \\
\text { Pattern }\end{array}$ & $\begin{array}{ll}\text { 1, Group members discussion } \\
\text { 2, Group representative } \\
\text { discussion } \\
\text { 3, Teacher students discussion } \\
\text { 4, Discussion via corpora }\end{array}$ \\
\hline
\end{tabular}

A. Discussion Presentation by Group 3

Chinese Linguistics Research Center in Peking University, developed CCL corpus, updated July 20, 2009. Corpus size: 477 million word (1.06GB). Of "knowledge explosion", "information explosion" and "population explosion" retrieval, the query results are as follows:

38 "knowledge explosions" are distributed as the following table 3 :

Table III

\begin{tabular}{|l|l|}
\hline Field & Amount \\
\hline news & 1 \\
\hline newspaper & 13 \\
\hline magazine & 16 \\
\hline trade & 2 \\
\hline Software education & 1 \\
\hline TV\& movie & 4 \\
\hline psychology & 1 \\
\hline
\end{tabular}

52 "information explosions" are distributed as the following table 4 :
Table IV

\begin{tabular}{|l|l|}
\hline Field & Amount \\
\hline news & 2 \\
\hline newspaper & 23 \\
\hline magazine & 13 \\
\hline TV\& movie & 4 \\
\hline education & 3 \\
\hline stock & 1 \\
\hline Economy management & 1 \\
\hline Practical text & 4 \\
\hline psychology & 1 \\
\hline
\end{tabular}

72"information explosions" are distributed as the following table 5:

Table V

\begin{tabular}{|l|l|}
\hline Field & Amount \\
\hline News & 5 \\
\hline Newspaper & 27 \\
\hline magazine & 24 \\
\hline economy & 1 \\
\hline politics & 1 \\
\hline history & 8 \\
\hline science & 1 \\
\hline Education & 3 \\
\hline Stock & 1 \\
\hline Movie & 1 \\
\hline Management & 1 \\
\hline
\end{tabular}

According to the three tables, Statistics (CCL corpus information, July 20, 2009) is as follows: "knowledge explosion" cited 32 times, in the 7 fields; "information explosion" reference 52 times, in the 9 fields; "population explosion" cited 73 times, in the 11 fields. "Information explosion" and "population explosion" of the frequency of use and the use of the field is on the rise. As shown in the diagram presented below.

Diagram 1

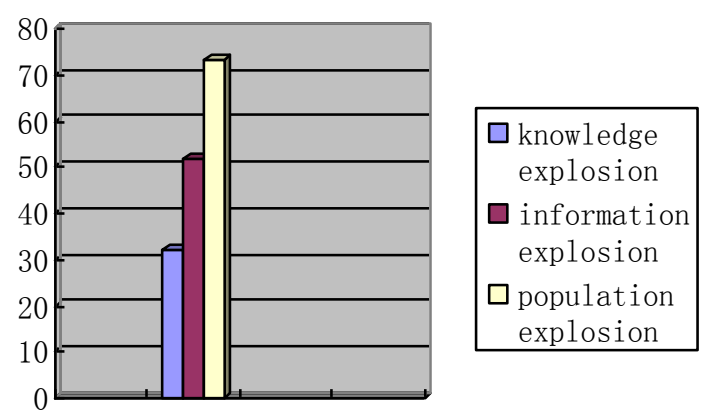

The word used in the following phrases: "knowledge explosion", "information explosion" and "population explosion", is translated as the entry of " [countable, uncountable] the sudden violent bursting and loud noise of something such as a bomb exploding." 


\section{B. Discussion Presentation by Group 1}

Expression of explosion in the new Oxford English and Chinese Dictionary is as the following:

1) [countable, uncountable] the sudden violent bursting and loud noise of something such as a bomb exploding; the act of deliberately causing something to explode. Phrases: a bomb/nuclear/gas explosion.

2) [countable] a large, sudden or rapid increase in the amount or number of something. Phrases: a population explosion; an explosion of interest in learning Japanese; an explosion in oil prices.

3) [countable] (formal) a sudden, violent expression of emotion, especially anger.

\section{Discussion Presentation by Group 4}

Sentences in COCA and BNC were randomly selected as the following:

1) Just as teachers found the knowledge explosion and the publications explosion causes of considerable difficulty, so certainly did librarians, and a brief examination of some of the problems may at this point be instructive (EW7 582).

2) One of the major reasons, however, for the interest in resource-based learning has been the recognition that children must learn, during the course of their schooling, to be increasingly self-sufficient in learning, to become the "independent autonomous learners" most fitted to survive in a society undergoing constant change, and in the context of the knowledge explosion (EW7 1317).

3) The paradox about all this information explosion or whatever it is called is that the speed of its distribution is so high and the actual receiving of it by a human being is so necessarily slow and far more inefficient than it is achieved by other methods, such as reading printed marks on paper (B7G 2457).

4)The electronic information explosion knows no frontiers; we may soon be enveloped in a worldencompassing atmosphere of information messages and 'noise' of a variety and density not known before. (BNE 842).

5) The River Chelt flowed to the south of the town, but during the great population explosion between 1800 and the mid-1820s (the population grew from 3,000 to over $20,000)$, the built up area gradually encroached on the empty fields and spread towards it(ANC1385).

6) If the immortals were capable of reproduction there would be a colossal population explosion: imagine what it would be like if every human being ever born were still alive! (CET 1003)

\section{Discussion}

The 4 sentences mentioned above, obviously, the meaning of "explosion" are a large, sudden or rapid increase in the amount or number of something. There are more phrases such as publication explosion, job explosion, art explosion, price explosion, website explosion, video explosion, debt explosion etc.

How to determine the context meaning of the word "explosion"? In the 1920s, Malinowski, founder of functionalism pointed out that there is a close relationship between a language and its context and a context in comprehending a text is essential, and further stressed that only in "a context" and "the cultural context" a passage could be evaluated(Malinowski:1923). So from the perspective of a context the correct meaning could be singled out.

\section{CONCLUSIONS}

The design of teaching activities aimed at students' autonomous learning is of great help in fulfilling the teaching goals. The classroom teaching based on English or Chinese corpuses enriches the contents of courses, and encourage actively students to solve problems in learning a language. With the further study of the research on corpus, how to use the network corpus to construct the English teaching resources more effectively will be more significant.

\section{ACKNOWLEDGMENT}

I would like to express my heartfelt gratitude to Prof. Xu Mingwu, school of Foreign Languages, Central China University of Science \&Technology for his advice .

This paper is one of researches of 2015 Teaching and Research Project for Wuhan Municipal Universities entitled the Application of English Corpus-based Translation Teaching in English Majors of Chinese Universities.

\section{REFERENCES}

[1] Baker, M. Corpora in Translation Studies: An Overview and Some Suggestions for Future Research[J] . Target Vo. 1 7, 1995: 231.

[2] Laviosa, S. How comparable can comparable corpora be[J]. Target, 9,2: $289-319,1997$.

[3] The corpus- based approach: A new paradigm in translation studies[J]. Meta 43,4: 474-9, 1998a.

[4] Core patterns of lexical use in a comparable corpus of English narrative prose[J]. Meta 43,4: 557- 70, $1998 \mathrm{~b}$.

[5] Corpus- based Translation Studies: Theory, Findings , Applications[J]. Amsterdam/Atlanta, GA: Rodopi, 2002.

[6] Kenny, D. Creatures of habit? What translators usually do with words[J]. Meta 43,4: 515-23,1998.

[7] Lexis and Creativity in Translation[M]. Manchester: St. Jerome Publishing,2001.

[8] He Anping. corpus linguistic and English Teaching[M]. Beijing: Foreign Language Teaching and Research Press, 2004.

[9] Krashen, S. D. The Input Hypothesis : Issues and Implications[M] NY: Longman, Inc. 1985.

[10] Ellis R. Language Teaching Research and Language Pedagogy[M].Malden, MA: Wiley-Blackwell,2012.

[11] Gass S. Input, Interaction and the Second Language Learner[M]]Mahwah, NJ: Lawrence Erlbaum · Associates, 1997.

[12] Su Dingfang, A Study of New Model in Teaching Foreign Language[M]. Foreign Language World, 2006, (4) :21-29

[13] Malinowski , B."The Problems of Meanings in Primitive Language". In The Meaning of Meaning.Ed. C. K. Ogden, and A. Richards. New York : Harcourt, Brace and World, Inc , 1923. 